\title{
A ProteÇÃo do Patrimônio Genético Humano E AS INFORMAÇÕES GENÉTICAS CONTIDAS NOS BIOBANCOS
}

\author{
Mário Furlaneto Neto* \\ Bruna de Oliveira da Silva Guesso Scarmanhä**
}

1 Introdução. 2 Direito à Proteção do Patrimônio Genético Humano. 3 Dados e Informações Genéticas contidas nos Bancos de Dados e sua respectiva Proteção. 4 Considerações Finais. Referências.

\section{RESUMO}

O mundo globalizado e o desenvolvimento tecnológico-humano geram impactos positivos e negativos no meio social. O contexto em tela figura-se na preocupação dos operadores do direito em traçar diretrizes para tutelar, limitar e proteger tais paradigmas visando a resguardar o patrimônio genético humano e a preservar os direitos fundamentais. A pesquisa se justifica pela necessidade da proteção do patrimônio genético humano e das respectivas informações genéticas contidas nos biobancos. Por meio de revisão bibliográfica e legislativa, questiona-se se as informações genéticas das pessoas, armazenadas em banco de dados, estão seguras, assim como se o conteúdo do biobanco se enquadra no contexto do conceito de banco de dados estipulado pelo Marco Civil da Internet e do decreto regulamentador. Conclui-se que as informações e dados contidos nos biobancos condizem com o contexto de banco de dados disposto pelo Marco Civil e do decreto regulamentador, porém, tendo em vista que estão correlacionados com o patrimônio genético humano, o padrão de segurança estabelecido merece melhor regulamentação, a fim de proporcionar maior segurança e rigidez quanto à tutela da intimidade e da privacidade.

Palavras-chave: Patrimônio genético humano. Informações genéticas. Proteção. Biobancos.

* Professor titular da graduação e do Mestrado em Direito do Centro Universitário Eurípides de Marília (UNIVEM). Doutor em Ciência da Informação pela Universidade Estadual Paulista Júlio de Mesquita Filho. Mestre em Ciência da Informação pela Universidade Estadual Paulista Júlio de Mesquita Filho. Graduado em Direito pela Faculdade de Direito de Marília Fundação Eurípides Soares da Rocha. E-mail: <mariofur@univem.edu.br>.

** Mestranda em Direito pelo Centro Universitário Euripedes de Marília. Graduada em Direito pelo Centro Universitário Euripedes de Marília. E-mail: < bruna.guesso@gmail.com>. 


\section{INTRODUÇÃO}

O patrimônio genético é o conjunto de informações que formam o DNA, constituindo a identidade de cada indivíduo, sendo que a estrutura genética é a mesma, porém cada qual com suas combinações.

Desse modo, os genes contidos no DNA decidem o fenótipo de uma pessoa sendo, ainda, capazes de provocar mudanças no comportamento humano, que possui origem genética.

Com efeito, o patrimônio genético humano deve ser protegido pelos ordenamentos jurídicos, tendo em vista que a manipulação destes pode provocar danos irreversíveis à humanidade.

Assim, levando-se em conta que o patrimônio genético assume tal importância, observa-se que suas respectivas informações genéticas, contidas em banco de dados digitais de clínicas, laboratórios e de grandes empresas, devem ser preservadas de modo que assegure a total proteção dos dados ali contidos, evitando, dessa forma, invasões ou, ainda, vazão de informações que podem causar prejuízos e danos aos pacientes.

Assim sendo, a discussão proposta mostra-se relevante e se justifica em virtude da necessidade da efetiva proteção ao patrimônio genético humano e às respectivas informações genéticas contidas nos bancos de dados digitais (biobancos), máxime à vista da tutela dos dados pessoais e da proteção à privacidade previstos na Lei $\mathrm{n}^{\mathrm{o}}$ 12.965/2014, em especial diante da possibilidade de eventual violação das informações, a ponto de gerar danos e prejuízos, muitas vezes, irreversíveis, à pessoa proprietária dos dados genéticos depositados.

Dessa forma, o escopo da abordagem é analisar, por meio de revisões bibliográfica e legislativa, o conceito de patrimônio genético humano, assim como os conceitos de dados e informações genéticas, a fim de estabelecer critérios para efetivar a tutela, nomeadamente, diante dos parâmetros estabelecidos pelo Marco Civil da Internet e pelo decreto regulamentador.

Para tanto, como alicerce e referencial teórico, enfrentar-se-ão as dimensões dos direitos e garantias individuais da pessoa humana e os novos direitos, em especial no que se refere ao patrimônio genético humano, o que se fará a seguir.

\section{DIREITO À PROTEÇÃO DO PATRIMÔNIO GENÉTICO HUMANO}

A difusão de pesquisas com humanos e suas respectivas manipulações genéticas exploram a possível cura de enfermidades e as probabilidades de evitá-las. Com os avanços biotecnológicos, passam-se a exigir do Direito regulamentações para tutelar, limitar e proteger tais paradigmas visando a resguardar o patrimônio genético humano e a preservar os direitos fundamentais.

O patrimônio genético humano é um dos maiores bens da humanidade, sendo este definido por Lehninger ${ }^{1}$ como "[...] o conjunto de elementos que 
formam o ácido desoxirribonucléico - DNA - que é o possuidor da informação genética, que caracteriza um organismo".

Para Levine, ${ }^{2}$ patrimônio genético "é a somatória dos caracteres inerentes a um organismo que se manifesta por meio dos fenótipos e dos genótipos".

Diaféria ${ }^{3}$ explica que:

os fenótipos são as informações que caracterizam as expressões externas de um organismo, ou seja, suas características físicas, como cor da planta ou orelhas, cabelos, cor de olhos, sexo, etc. Essas informações são determinadas pelos genótipos e, também, pela influência das condições ambientais. Porém, as alterações ambientais do fenótipo não refletem alterações no genótipo, mas, sim, na resposta do organismo ao seu ambiente e nas atitudes comportamentais do ser vivo diante dessa influência. $\mathrm{O}$ ambiente, portanto, fornece a "arena" na qual o genótipo age; e, consequentemente, o fenótipo representa a expressão final da interação do genótipo com o ambiente. Já os genótipos são as informações que se transmitem de uma geração a outra, ou seja, são um composto de vários genes, que possuem propriedades químicas e físicas específicas, que determinam a natureza do fenótipo. Cada gene tem a capacidade de se autorreproduzir, e raramente essa reprodução conduz a um gene com propriedades diferentes do original. Com isso, é mantida a continuidade do genótipo de uma geração a seguinte.

Entretanto, Barbas ${ }^{4}$ vai além da definição do patrimônio genético e o distingue do genoma humano. Assim, patrimônio genético é o

[...] universo de componentes físicos, psíquicos e culturais que começam no antepassado remoto, permanecem constantes, embora com naturais mutações ao longo das gerações, e que, em conjugação com fatores ambientais e num permanente processo de interação, passam a constituir a nossa própria identidade e que, por isso, temos o direito de guardar e defender e depois transmitir. O genoma humano determina o património genético porque, se o genoma de um indivíduo for manipulado geneticamente (antes de seu próprio nascimento), este fica, à partida, alterado, condicionado às limitações impostas pelo genoma modificado. Ou seja, o património genético vai ser, desde logo, diferente porque cada pessoa vai ter o seu modo de ser, de pensar, e estar no mundo condicionado, ab initio, pelo que o genoma permite. Mas, por outro lado, o património genético transcende o genoma, uma vez que abrange outras realidades para além do próprio genoma.

Desta feita, de acordo com o entendimento de Pereira do Vale, ${ }^{5}$ "[...] DNA, molécula responsável pela informação genética, situada no núcleo da célula, que faz parte dos cromossomos, determinante do fenótipo (carac- 
terísticas apresentadas pelo indivíduo, de ordem morfológica, fisiológica ou comportamental)" e o "genótipo (refere-se à constituição genética do indivíduo, ou seja, aos genes que ela possui, que determinam o fenótipo do indivíduo) dos indivíduos [...]" causam "[...] causam alterações, tanto na fisionomia do homem, como na sua maneira de Ser", isto porque "comportamentos humanos têm origem genética".

Ao corroborar tal posicionamento, Barbas ${ }^{6}$ preceitua que "o fenótipo é dinâmico, emerge da interação do genótipo como um todo (milhares de genes) com complexo ambiente. A pessoa é, por excelência, um ser circunstanciado".

Logo, observa-se que os genes são os que decidem o fenótipo de uma pessoa, sendo ainda capazes de provocar mudanças no comportamento humano, que possui origem genética.

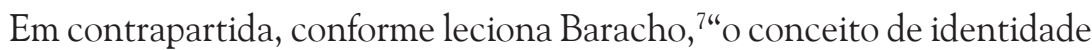
genética corresponde ao genoma de cada ser humano e às bases biológicas da sua identidade".

Assim, todos os indivíduos possuem a mesma estrutura molecular, mas diferenciando-se no conjunto de combinações do DNA.

Por outra banda, a Declaração Universal do Genoma Humano e dos Direitos Humanos dispõe no artigo $1^{\circ}$ que: "O genoma humano subjaz à unidade fundamental de todos os membros da família humana e também ao reconhecimento de sua dignidade e diversidade inerentes. Num sentido simbólico, é a herança da humanidade." ${ }^{8}$

Isto é, em sentido simbólico, o genoma humano é patrimônio da humanidade, sendo que a responsabilidade de proteção e preservação do patrimônio genético é de toda a humanidade.

Em seu artigo $10^{\circ}$, disciplina a Declaração Universal do Genoma Humano e dos Direitos Humanos que:

Nenhuma pesquisa ou suas aplicações relacionadas ao genoma humano, particularmente nos campos da biologia, da genética e da medicina, deve prevalecer sobre o respeito aos direitos humanos, às liberdades fundamentais e à dignidade humana dos indivíduos ou, quando for aplicável, de grupos humanos. ${ }^{9}$

Nesse diapasão, em decorrência da evolução social, surgem novos direitos e diretrizes para a proteção dos novos pressupostos sociais, alvo de tutela dos direitos de terceira e quarta dimensões. Aqui, destaca-se a qualidade de vida, o progresso e os avanços biotecnológicos, discussão esta que surge na terceira dimensão ${ }^{10}$ e que se estende à quarta dimensão de direitos fundamentais.

Com efeito, de acordo com Canotilho, ${ }^{11}$ "os direitos fundamentais cumprem a função de direitos de defesa dos cidadãos sob uma dupla perspectiva", isto é, em um primeiro plano, "constituem, num plano jurídico-objetivo, normas de 
competência negativa para os poderes públicos, proibindo fundamentalmente as ingerências destes na esfera jurídica individual” e, em uma segunda dimensão, "implicam, num plano jurídico-subjetivo, o poder de exercer positivamente direitos fundamentais (liberdade positiva) e de exigir omissões dos poderes públicos, de forma a evitar agressões lesivas por parte dos mesmos (liberdade negativa)".

Em consonância, preceitua Miranda ${ }^{12}$ que "por direitos fundamentais entendemos os direitos ou as posições jurídicas subjetivas das pessoas enquanto tais, individual ou institucionalmente consideradas, assentes na Constituição, seja na Constituição formal, seja na Constituição material - donde, direitos fundamentais em sentido formal e direitos fundamentais em sentido material".

Assim,

A terceira dimensão de direitos tem por finalidade básica a coletividade, ou seja, proporcionar o bem-estar dos grandes grupos, que, muitas vezes, são indefinidos e indeterminados, como o direito ao meio ambiente e à qualidade de vida, direitos esses reconhecidos atualmente como difusos ${ }^{13}$.

Moraes ${ }^{14}$ diz que se asseguram constitucionalmente "como direitos de terceira geração os chamados direitos de solidariedade ou fraternidade, que englobam o direito a um meio ambiente equilibrado, a uma saudável qualidade de vida, ao progresso, à paz, à autodeterminação dos povos e a outros direitos difusos $[\ldots] . "$

Pérez Luño, ${ }^{15}$ em sua obra La Tercera Generación de Derechos Humanos, enfatiza que a terceira dimensão é uma resposta à poluição das liberdades, ${ }^{16}$ ante a determinados usos das novas tecnologias que estão degradando os direitos fundamentais. Com efeito, literalmente é o que ocorre nos dias atuais com o avanço das pesquisas biotecnológicas envolvendo o patrimônio genético humano, sem a efetiva e a devida proteção, origina-se a "poluição da liberdade tecnológica" na seara do biodesenvolvimento.

Contudo, a biotecnologia destaca-se na quarta dimensão, sendo que:

Os direitos humanos de quarta e quinta dimensão seriam aqueles que surgiram dentro da última década, devido ao grau avançado de desenvolvimento tecnológico da humanidade, sendo estes ainda apenas pretensões de direitos. No caso da quarta geração, pode-se colocar que seriam os direitos ligados à pesquisa genética, surgida da necessidade de se impor uns controles à manipulação do genótipo dos seres, em especial o do ser humano. ${ }^{17}$

Em contrapartida, Bonavides ${ }^{18}$ entende que são direitos de quarta geração a democracia, a informação e o pluralismo, decorrentes da globalização dos direitos fundamentais. Segundo a lição de Bonavides, ${ }^{19}$ "os direitos da quarta geração não somente culminam a objetividade dos direitos das duas gerações antecedentes como absorvem - sem, todavia, removê-la - a subjetividade dos direitos individuais [...]." 
Noberto Bobbio ${ }^{20}$ elenca, em "A Era dos Direitos", que as dimensões apenas surgem para impedir malefícios ou obter benefícios do poder que nasce das mudanças derivadas das condições sociais, ao enfatizar que:

[...] os direitos não nascem todos de uma vez. Nascem quando devem ou podem nascer. Nascem quando o aumento do poder do homem sobre o homem - que acompanha inevitavelmente o progresso técnico, isto é, o progresso da capacidade do homem de dominar a natureza e os outros novos homens - ou cria novas ameaças à liberdade do indivíduo, ou permite novos remédios para as suas indigências. ${ }^{21}$

Assim, para Bobbio, ${ }^{22}$ "[...] já se apresentam novas exigências que só poderiam chamar-se de direitos de quarta geração, referentes aos efeitos cada vez mais traumáticos da pesquisa biológica, que permitirá manipulações do patrimônio genético de cada indivíduo".

De outro lado, Motta $\&$ Barchet $^{23}$ dizem que, com essa geração, "urge a necessidade de seu reconhecimento para que não fique o mundo jurídico apartado da evolução científica”.

Deveras, preleciona Bobbio ${ }^{24}$ que, em virtude de nos encontrarmos em uma era de tecnologia avançada, e, em razão de que a engenharia genética tende a criar soluções para os problemas humanos, pode ser dito que os direitos de quarta geração nasceram, porque foi propício seu nascimento.

Desta feita, a quarta dimensão dos direitos fundamentais cuida das manipulações do patrimônio genético, "se ocupando do redimensionamento de conceitos e limites biotecnológicos e, por isso, são direitos fundamentais relativos à humanidade". 25

Nesse passo, aponta Maluf ${ }^{26}$ que "[...] insere-se o biodireito nessa quarta geração de direitos humanos, pois grande é a preocupação atual em se normatizarem os efeitos da Revolução biotecnológica sobre a sociedade [...]", em decorrência da "[...] preocupação com a difusão dessas novas tecnologias, com a humanização do ambiente hospitalar, com a proteção dos direitos dos pacientes, visando, assim , a integrar a ética com as ciências biomédicas".

É indubitável que as dimensões existem para salvaguardar direitos fundamentais, pois, por trás da quarta dimensão, é possível vislumbrar bens e valores axiológicos que necessitam de proteção, como o patrimônio genético humano e a respectiva vida. Cumpre esclarecer que, a biotecnologia acerca das pesquisas em torno da genética humana tem como fito a concretização do direito à saúde, assim, observa-se que a quarta dimensão efetiva a terceira dimensão dos direitos fundamentais.

Com efeito, quando se discute a tutela jurídica do material genético sob a ótica dos direitos fundamentais, busca-se assegurar a proteção ao patrimônio genético humano diante dos novos avanços. 
Nesse sentir, diante dos avanços decorrentes da engenharia genética, destaca-se que, atualmente, já é possível identificar, por meio dos genes, futuras enfermidades que poderão afetar certos indivíduos. Nas palavras de Barbas, ${ }^{27}$ "[...] estão já identificados e isolados genes humanos que explicam não só a origem como, ainda, as características de diversas enfermidades hereditárias".

Barbas ${ }^{28}$ explica que, "[...] graças aos testes genéticos, é possível predizer, com bastante antecedência, doenças de que indivíduos aparentemente sãos virão a sofrer muitos anos mais tarde." Além disso, é possível "descobrir' no genoma predisposições para determinadas enfermidades cuja manifestação está dependente do ambiente, da alimentação, etc", sendo, ainda, "também já viável verificar se uma pessoa sã é portadora de uma doença que poderá transmitir às gerações vindouras, apesar de nunca vir a padecer dela".

Desse modo, perante as novas implicações na vida humana, discorre Diaféria ${ }^{29}$ que, "[...] ao tratar-se das questões atreladas à manipulação genética do material humano, o objeto da proteção seria o próprio ser humano, não somente como indivíduo, mas, também, como gênero humano".

Pois, de acordo com Barbas, ${ }^{30}$ "a sujeição a um exame genético pode, ainda, pôr em causa o direito à privacidade do testado. A informação genômica constitui o núcleo, o cerne mais profundo da nossa intimidade biológica", logo, "toda pessoa deve ter o direito de conhecer os elementos de investigação médica que lhe digam respeito e, em paralelo, o direito de preservar o conhecimento desses dados exclusivamente para si numa concepção mais ampla de privacidade".

Assim, os dados e informações contidos nos bancos de dados devem ser preservados e protegidos, sob o risco de violação da privacidade e lesão ao patrimônio genético humano.

\section{DADOS E INFORMAÇÕES GENÉTICAS CONTIDAS NOS BANCOS DE DADOS E SUA RESPECTIVA PROTEÇÃO}

O avanço biotecnológico em torno da manipulação do patrimônio genético gera preocupação acerca de sua respectiva preservação. Assim, nessa seara, os bancos de dados laboratoriais, médicos e de grandes empresas assumem papel de grande importância, haja vista a necessidade de proteger as informações genéticas ali contidas.

Nesse passo, os elementos genéticos contidos no DNA humano compõem um patrimônio de informações, os quais, mapeados e armazenados para análise ou ainda pesquisas, são mantidos em banco de dados a fim de subsidiar diagnósticos futuros aos pacientes.

Com efeito, conforme considera Morgato, ${ }^{31}$ "[...] a biotecnologia tem viabilizado procedimentos médicos que possibilitam a cura de muitas doenças e a prevenção de outras, porém também gera situações tormentosas, uma vez que poderá capacitar o homem para programar a vida humana em laboratório [...]". 
Assim, diante da preocupação em preservar o patrimônio genético humano frente aos novos procedimentos médicos-científicos, deve-se ater à inviolabilidade dos dados e às informações genéticas.

Perez Luño, ${ }^{32}$ ao discorrer sobre a tutela dos dados pessoais no âmbito da biomedicina, enfatiza que:

A tensão surge, precisamente, da exigência dos poderes públicos de utilizar a transmissão desses dados médicos, especialmente aqueles que se referem a doenças contagiosas, ou aqueles que podem ser usados para o desenvolvimento de avanços na pesquisa científica e o desejo dos cidadãos de manter um controle sobre as informações que lhes dizem respeito. ${ }^{33}$

Desse modo, observa-se que as informações e dados contidos nos bancos de dados laboratoriais, médicos e de grandes empresas estão sujeitos a invasões e a vazões dos elementos ali armazenados, visto que a preservação da diversidade e a integridade do patrimônio genético devem ser objeto de proteção.

As expressões, os dados e as informações implicam uma relação de gênero e espécie. Assim, tudo o que trafega no meio ambiente da Internet é um dado (gênero), enquanto a informação (espécie) é o dado que deve trafegar de forma sigilosa, ou seja, de conhecimento apenas das partes interessadas. Assim, os dados pessoais se inserem no contexto das informações, uma vez que devem ser protegidos nos termos do Marco Civil da Internet.

Sob essa dimensão, Davara Rodríguez ${ }^{34}$ explica que os dados pessoais têm conexão com a intimidade (unidos ao indivíduo e em seu entorno social) e que a privacidade é a possibilidade de mantê-los em sigilo, resguardados de acesso e intromissões alheias.

Nessa seara, os bancos que contêm os dados e as informações genéticas são chamados de biobancos. De acordo com Souza: ${ }^{35}$

Embora relativamente recente, o termo biobanco (derivado da palavra inglesa biobank) é atualmente de uso corrente entre os profissionais da área da saúde, e o seu conceito pode ser compreendido como todo repositório de material biológico, no qual, de forma organizada e com objetivos definidos, são armazenadas amostras biológicas e informações associadas; ou, então, como coleções de amostras de substâncias corporais (v.g., células, tecidos, sangue, ou DNA) que são ou podem ser associadas com os dados pessoais e informação sobre seus doadores. De acordo com a finalidade, há dois tipos de biobancos médicos: a) biobancos assistenciais (diagnósticos e terapêuticos); e b) biobancos para pesquisa.

Partindo desse pressuposto, os biobancos devem assegurar máxima proteção aos proprietários dos materiais genéticos ali contidos, tendo em vista a necessidade de preservação do sigilo dos dados pessoais e das informações.

Nessa dimensão, preceitua Souza ${ }^{36}$ que 
[...] o biobanco deve organizar um sistema de informação e segurança garantindo que os dados pessoais dos sujeitos de pesquisa serão suficientemente protegidos no que se refere à confidencialidade das informações associadas às amostras, isto é, deve conter um sistema seguro de identificação, que garanta o sigilo, o respeito à confidencialidade e à recuperação dos dados dos sujeitos da pesquisa, para fornecimento de informações do interesse destes.

Deveras, o indivíduo possui o direito de manter aspectos de sua vida em sigilo, seja no âmbito familiar, profissional ou social. Destarte, a informação de caráter íntimo ou privado de cada pessoa, não poderá ser manipulada sem o consentimento do usuário, sob pena de violar a tutela à liberdade.

Nessa seara, Montesquieu ${ }^{37}$ conceitua a liberdade como "o direito de fazer tudo o que as leis permitem", contudo Silva ${ }^{38}$ adverte que esse conceito traz um risco, pois deve levar em consideração, para fins de validade, leis consentidas pelo povo. Mais aceitável, de acordo com Silva, ${ }^{39}$ é o conceito trazido pela Declaração de 1789, que condicionava o direito à liberdade aos limites que tangenciam os direitos dos demais membros da sociedade, que têm direito ao gozo dos mesmos direitos. Destaca que apenas a lei pode estabelecer tais limites, isto é, senão aqueles que sejam nocivos à sociedade.

Nessa dimensão, o conceito de liberdade, frente ao armazenamento de dados, abrange outros direitos fundamentais, tais como a privacidade, a intimidade e a vida privada.

Assim, dispõe o artigo $5^{\circ}$, inciso X, da Constituição Federal, acerca da inviolabilidade da intimidade, da vida privada, da honra e da imagem das pessoas. ${ }^{40}$

Nas palavras de Lafer, ${ }^{41}$ privacidade é "o direito do indivíduo de estar só e a possibilidade que deve ter toda pessoa de excluir do conhecimento de terceiros aquilo que a ela só se refere, e que diz respeito ao seu modo de ser no âmbito da vida privada".

$\mathrm{Na}$ definição de Bastos, ${ }^{42} \mathrm{o}$ direito à privacidade é "a faculdade que tem cada indivíduo de obstar a intromissão de estranhos em sua vida privada e familiar, assim como de impedir-lhes o acesso a informações sobre a privacidade de cada um, e também impedir que sejam divulgadas informações sobre esta área da manifestação existencial do ser humano" .

Nesse passo, Silva ${ }^{43}$ conceitua a privacidade como gênero, dos quais são espécies a intimidade, a vida privada, o direito à honra, à imagem das pessoas, entre outros. Dessa maneira, a privacidade compõe um conjunto mais amplo que a intimidade, pois todo íntimo é privado, mas nem todo o privado é íntimo, a ponto de agrupar no direito à privacidade.

Logo, "o conceito de direito à privacidade é subjetivo, pois é inerente a cada indivíduo delimitar os fatos e informações que deseja manter sob sigilo". ${ }^{4}$ 
Dotti ${ }^{45}$ conceitua a intimidade como "a esfera secreta da vida do indivíduo na qual este tem o poder legal de evitar os demais," isto é, evitar disponibilizar ao conhecimento de outrem aquilo que é pessoal, íntimo ou particular.

Nota-se que os dados e as informações genéticas contidas nos bancos de dados merecem e devem ter a respectiva proteção, sob o manto da intimidade, da privacidade e da vida privada, pois, conforme explana Echterhoff, ${ }^{46}$ são "amplas possibilidades de ofensa ao direito à privacidade que o acesso, indiscriminado e ilegal, aos dados genéticos de uma determinada pessoa pode causar."

Explica Echterhoff ${ }^{47}$ que "[...] com a compreensão do genoma humano, o tratamento de doenças genéticas está deveras facilitado", sendo que "[...] esses testes podem confirmar diagnóstico, identificar portadores (sadios) de um gene patogênico e fornecer informações pré-sintomáticas, incluindo riscos de doenças futuras e morte precoce", bem como "podem também revelar informações não somente sobre o indivíduo, mas sobre seus familiares".

Assim, mesmo diante das inúmeras possibilidades que por vezes são benéficas, em caso de violação e propagação dos dados e informações genéticas, estes podem provocar discriminação e exclusão social, isto é, causar um processo de banimento e privação de certas pessoas ou grupos da sociedade.

Bandeira e Scariot ${ }^{48}$ explanam que "[...] a intimidade e a privacidade genéticas são mais do que meras inquietudes científicas: envolvem sérios problemas éticos, com repercussão no cotidiano das pessoas [...]".

Nesse sentido, advertem Bandeira e Scariot ${ }^{49}$ que:

Ao lado do grande entusiasmo provocado pelos avanços da genômica e da ansiedade sobre as descobertas que ainda estão por vir, há uma outra realidade que vem evoluindo a passos lentos no meio social, mas que já preocupa. Trata-se de uma nova espécie de discriminação, fundada nos caracteres genéticos, prática que vem se difundindo especialmente no âmbito trabalhista, na exclusão de emprego para os portadores de anomalias genéticas, e de contratos de seguro.

Em decorrência da aquisição de conhecimentos na área genética, relativos à influência dos genes na determinação do comportamento do homem e no surgimento de doenças congênitas, ativistas e associações americanas e europeias temem o surgimento de um genetic under class (seres humanos de uma subclasse genética), considerada não empregável em razão do surgimento de uma nova forma de discriminação, de mais um atentado ao princípio da igualdade, denominada "discriminação genética".

Dessa forma, constata-se que os riscos de discriminação e exclusão social estão relacionados, com a informação e sua respectiva aquisição, e ainda, com a utilização inapropriada e abusiva desses dados e informações contidos em biobancos. 
Nessa seara, Echterhoff ${ }^{50}$ afirma que:

[...] analisando detidamente o conceito de direito à privacidade, o âmbito das técnicas de engenharia genética que têm finalidades diagnósticas e as diversas consequências do conhecimento das informações genéticas humanas, constata-se claramente que os dados genéticos, como informações diretamente relacionadas ao ser humano, são integrantes da esfera íntima do homem, devendo ser protegidos [...].

Outrossim, nota-se que o princípio da confidencialidade contido na Declaração Universal do Genoma Humano e dos Direitos Humanos demonstra a preocupação com a má utilização das informações genéticas, isto porque, segundo Echterhoff, " 5 "...] dentro do conceito de privacidade, inclui-se o de confidencialidade que se traduz no direito do indivíduo a determinar as circunstâncias nas quais deve ser revelada a informação genética e a quem se deve revelar [...]”.

Nesse sentido, Diaféria ${ }^{52}$ preleciona acerca do princípio da confidencialidade ao enfatizar que "as informações que serão passadas após a realização da manipulação são estritamente confidenciais, não sendo permitido o conhecimento do conteúdo do resultado a nenhuma outra pessoa, além da detentora do material genético experimentado, a não ser que esta autorize expressamente."

Desse modo, constata-se que as informações e os dados genéticos afetam, além do entorno social dos portadores de anomalias, os seus respectivos entes familiares, motivo pelo qual a proteção aos biobancos deve ser eficiente.

Assim, partindo-se do pressuposto de que o Marco Civil da Internet (Lei $\left.n^{\circ} 12.965 / 2014\right)$, em especial no que se refere ao artigo $3^{\circ}$, assegura que "a disciplina do uso da internet no Brasil tem os seguintes princípios: [...] II - proteção da privacidade; III - proteção dos dados pessoais, na forma da lei; $[\ldots]]^{5},{ }^{53}$ bem como a dispõe em seu artigo $7^{\circ}$ :

O acesso à internet é essencial ao exercício da cidadania, e ao usuário são assegurados os seguintes direitos: I - inviolabilidade da intimidade e da vida privada, sua proteção e indenização pelo dano material ou moral decorrente de sua violação; [...] VII - não fornecimento a terceiros de seus dados pessoais, inclusive registros de conexão, e de acesso a aplicações de internet, salvo mediante consentimento livre, expresso e informado ou nas hipóteses previstas em lei; $[\ldots] .{ }^{54}$

E, além disso, disciplina em seu artigo $10^{\circ}$ que:

A guarda e a disponibilização dos registros de conexão e de acesso a aplicações de internet de que trata esta Lei, bem como de dados pessoais e do conteúdo de comunicações privadas devem atender à preservação da intimidade, da vida privada, da honra e da imagem das partes direta ou indiretamente envolvidas. $\S$ $1^{\circ} \mathrm{O}$ provedor responsável pela guarda somente será obrigado a disponibilizar os registros mencionados no caput, de forma 
autônoma ou associados a dados pessoais ou a outras informações que possam contribuir para a identificação do usuário ou do terminal, mediante ordem judicial, na forma do disposto na Seção IV deste Capítulo, respeitado o disposto no art. $7^{\circ}$. [... $\$ 4^{\circ}$ As medidas e os procedimentos de segurança e de sigilo devem ser informados pelo responsável pela provisão de serviços de forma clara e atender a padrões definidos em regulamento, respeitado seu direito de confidencialidade quanto a segredos empresariais. ${ }^{55}$

Constata-se que o conceito de dados pessoais e os padrões de segurança estão previstos no Decreto 8.771, de 11 de maio de 2016. Desse modo, pode-se dizer que o conteúdo do biobanco se enquadra no contexto do conceito de banco de dados estipulado pelo Marco Civil e do decreto regulamentador, porém, tendo em vista que se trata do patrimônio genético humano, o padrão de segurança estabelecido deve ser aprimorado, proporcionando maior segurança e rigidez, visando à tutela da intimidade e da privacidade dos envolvidos.

Destaca-se que o biobanco é composto por dois segmentos: o armazenamento do material biológico e o armazenamento de dados, como o resultado na análise do DNA, os resultados dos exames realizados e os dados pessoais dos pacientes. No entanto, a discussão ora proposta se preocupa com o entorno do armazenamento dos dados pessoais e do seu respectivo padrão de segurança.

O Decreto regulamentador conceitua dados pessoais como sendo todos aqueles relacionados "à pessoa natural ou identificável, inclusive números identificativos, dados locacionais ou identificadores eletrônicos quando estes estiveram relacionados a uma pessoa". ${ }^{56}$ Desse modo, o acervo dos biobancos contêm dados ou informações relacionados à pessoa natural, passíveis de tratamento, quando pertinentes às operações de "coleta, produção, recepção, classificação, utilização, acesso, reprodução, transmissão, distribuição, processamento, arquivamento, armazenamento, eliminação, avaliação ou controle da informação, modificação, comunicação, transferência, difusão ou extração", 57 motivo pelo qual, tais operações devem ser operacionalizadas dentro de um rigoroso padrão de segurança, nomeadamente, em face da importância e dos reflexos decorrentes da tutela de direitos personalíssimos a que as informações que compõem os biobancos correspondem.

Partindo do pressuposto de que o biobanco se enquadra no contexto da aplicação de Internet, o Decreto n ${ }^{0}$ 8.771/2016 impõe critérios mínimos de segurança a serem observados pelo provedor, ou seja:

I - o estabelecimento de controle estrito sobre o acesso aos dados mediante a definição de responsabilidades das pessoas que terão possibilidade de acesso e de privilégios de acesso exclusivo para determinados usuários; II - a previsão de mecanismos de autenticação de acesso aos registros, usando, por exemplo, sistemas de autenticação dupla para assegurar a individualização do responsável pelo tratamento dos registros; III - a criação de inventário detalhado dos acessos aos registros de conexão e de acesso a aplicações, 
contendo o momento, a duração, a identidade do funcionário ou do responsável pelo acesso designado pela empresa e o arquivo acessado, inclusive para cumprimento do disposto no art. $11, \S 3^{\circ}$, da Lei $n^{0} 12.965$, de 2014; e IV - o uso de soluções de gestão dos registros por meio de técnicas que garantam a inviolabilidade dos dados, como encriptação ou medidas de proteção equivalentes. ${ }^{58}$

Verifica-se, portanto, que o provedor do biobanco deve proporcionar controle de acesso, níveis de privilégio, ${ }^{59}$ registro de $\operatorname{logs}{ }^{60}$ e criptografia, ${ }^{61}$ porém outros padrões de segurança devem ser observados, nomeadamente, no que tange à infraestrutura da rede e sistema, assim como critérios para backups, visando à tutela da intimidade e da privacidade.

\section{CONSIDERAÇÕES FINAIS}

O referencial teórico apresentado possibilitou concluir que os avanços biotecnológicos relativos ao patrimônio genético humano e a seu respectivo conteúdo armazenado em biobancos merecem maior atenção e rigidez legislativa, por se tratarem do maior legado humano, isto é, sua própria genética, sendo capazes de provocar mudanças no comportamento e alterações nas bases biológicas da sua identidade.

Assim, os dados e informações contidos nos bancos de dados devem ser preservados e protegidos, sob o risco de violação da privacidade e lesão ao patrimônio genético humano.

De fato, o conceito de dados pessoais e os padrões de segurança estão previstos no Decreto 8.771, de 11 de maio de 2016. In casu, buscou-se analisar se o conteúdo do biobanco se enquadra no contexto do conceito de banco de dados estipulado pelo Marco Civil e do decreto regulamentador.

Os direitos e garantias individuais da pessoa humana devem ser preservados, pois, mesmo diante das inúmeras possibilidades proporcionadas pela engenharia genética, que muitas vezes são benéficas, em caso de violação e propagação dos dados e informações genéticas, estas podem provocar a discriminação e a exclusão social, culminando em um processo de banimento e privação de certas pessoas ou grupos da sociedade em diversos setores sociais.

Conclui-se, portanto, que os dados e informações armazenados em biobancos se enquadram no contexto do conceito de banco de dados estipulado pelo Marco Civil e do decreto regulamentador. Contudo, o padrão de segurança estabelecido no Decreto regulamentador se preocupou apenas com alguns aspectos, mais voltados à segurança da manutenção do controle de acesso, havendo a necessidade de compreender outros aspectos, como a segurança da rede e do sistema, assim como o método para elaboração de backups, visando a salvaguardar, com maior propriedade, o direito à privacidade e à intimidade, principalmente no que tange ao patrimônio genético humano.

Por fim, conclui-se que, diante dos avanços biotecnológicos, deve-se 
exigir do Direito maiores e melhores regulamentações para tutelar, limitar e proteger os novos paradigmas, objetivando resguardar o patrimônio genético humano e preservar os direitos fundamentais, respeitando os direitos humanos e em especial os bens jurídicos salvaguardados na Constituição Federal: a vida, a dignidade humana, o desenvolvimento, a privacidade e a intimidade.

\section{REFERÊNCIAS}

BANDEIRA, Ana Cláudia Pirajá; SCARIOT, Tatiane Botura. Discriminação genética e direitos da personalidade: problemas e soluções. Revista Jurídica Cesumar, Maringá, v. 6, n. 1, p. 47-73, 2006. Disponível em: <http://periódicos.unicesumar. edu.br/index.php/revjuridica/article/view/308 > . Acesso em: 13 ago. 2016.

BARBAS, Stela Marcos de Almeida Neves. Direito do genoma humano. Coimbra: Almedina, 2007.

BARACHO, José Alfredo de Oliveira. A identidade genética do ser humano: bioconstituição: bioética e direito. Revista de Direito Constitucional e Internacional, São Paulo, ano 8, n. 32, p. 88-92, jul./set. 2000. Disponível em: < http:// www.jurisite.com.br/textosjuridicos/texto74.html>. Acesso em: 3 ago. 2016.

BASTOS, Celso Ribeiro. Curso de Direito Constitucional. 21. ed. São Paulo: Saraiva, 2000.

BRASIL. Constituição Federal: de 05 de outubro de 1988. In: Vade Mecum compacto. 7. ed. São Paulo: Saraiva, 2012. p. 7-92.

. Lei ${ }^{\circ} 12.965$, de 23 de abril de 2014. Estabelece princípios, garantias, direitos e deveres para o uso da Internet no Brasil. Diário Oficial da República Federativa do Brasil, Brasília, DF, 24 abr. 2014. ed. 77. Seção 1. p.1. Disponível em: < http:// www.planalto.gov.br/ccivil_03/2014/lei/12965.htm>. Acesso em: 10 ago. 2016.

BOBBIO, Noberto. A era dos direitos. Tradução de Carlos Nelson Coutinho. Rio de Janeiro: Elsevier, 2004.

. A era dos direitos. 10. ed. Rio de Janeiro: Campus, 1992.

BONAVIDES, Paulo. Curso de Direito Constitucional. 30. ed. São Paulo: Malheiros, 2015.

CANOTILHO, José Joaquim Gomes. Direito Constitucional e Teoria da Constituição. 7. ed. Coimbra: Almedina, 2003.

DAVARA RODRÍGUEZ, Miguel Ángel. Manual de Derecho Informático. 10. ed. Navarra: Arazandi, 2008.

DIAFÉRIA, Adriana. Princípios estruturadores do direito à proteção do patrimônio genético humano e as informações genéticas contidas no genoma humano como bens de interesses difusos. 2000. Disponível em: <http://www. ghente.org/publicacoes/limite/principios.htm\#_ftn1 >. Acesso em: 2 ago. 2016. 
DOTTI, René Ariel. Proteção da vida privada e liberdade de informação. São Paulo: RT, 1980.

ECHTERHOFF, Gisele. Os dados genéticos e o direito à privacidade: a declaração universal sobre o genoma humano e os direitos humanos. Revista Eletrônica do CEJUR, Paraná, v. 1, n. 1, p. 206-239, ago./dez. 2006. Disponível em: <http://www.egov.ufsc.br/portal/sites/default/files/anexos/32023-37643-1-PB. pdf >. Acesso em: 13 ago. 2016.

MALUF, Adriana Caldas do Rego Freitas Dabus. Curso de bioética e biodireito. 3. ed. São Paulo: Atlas, 2015.

MARRONI, Fernanda. Quais são as dimensões de direitos fundamentais? 2011. Disponível em: <http://ww3.lfg.com.br/public_html/article. php?story $=2011062115424915>$. Acesso em: 4 ago. 2016.

MEIRA, Laís Moreschi de; SOARES, Matheus Fernandes de Souza; PIRES, Panmella Rodrigues. Direito à privacidade e as relações na Internet. 2012. Disponível em: <http://www.jurisway.org.br/v2/dhall.asp?id_dh $=7319>$. Acesso em: 13 ago. 2016.

MENDES, Jéssica Coura. Direitos de quarta dimensão. 2014. Disponível em: < https://jus.com.br/artigos/27836/direitos-de-quarta-dimensao >. Acesso em: 7 ago. 2016.

MIRANDA, Jorge. Manual de Direito Constitucional: tomo iv, direitos fundamentais. Coimbra: Editora Coimbra, 2012.

MORAES, Alexandre de. Direito Constitucional. 29. ed. São Paulo: Atlas, 2013. MORGATO, Melissa Cabrini. Bioética e Direito: limites éticos e jurídicos na manipulação do material genético. São Paulo: Letras Jurídicas, 2011.

MOTTA FILHO, Sylvia Clemente da; BARCHET, Gustavo. Curso de Direito Constitucional. 2. ed. Rio de Janeiro: Elsevier, 2009.

PÉREZ LUÑO, Antonio-Enrique. La tercera generación de Derechos Humanos. Navarra: Arazandi, 2006.

SILVA, José Afonso da. Curso de Direito Constitucional positivo. 39. ed. São Paulo: Malheiros, 2016.

SOUZA, Paulo Vinicius Sporleder de. Biobancos, dados genéticos e proteção jurídico-penal da intimidade. Revista da AMRIGS, Porto Alegre, v. 56, n. 3, p. 268-273, jul./set. 2012. Disponível em: < http://www.amrigs.org.br/revista/56-03/biobancos.pdf>. Acesso em: 13 ago. 2016.

UNESCO. Declaração Universal do Genoma Humano e dos Direitos Humanos. 1997. Elaborado pelo Comitê Internacional de Bioética, da UNESCO (Organização das Nações Unidas para a Educação, a Ciência e a Cultura), e apresentado na 29a Sessão da Conferência Geral da UNESCO, que aconteceu entre os dias 21 de outubro a 12 de novembro de 1997. Disponível em: < http://www1. folha.uol.com.br/fsp/1997/11/15/mundo/13.html>. Acesso em: 11 ago. 2016. 
1 (LEHNINGER, 1977, p. 375 apud DIAFÉRIA, 2000). DIAFÉRIA, Adriana. Princípios estruturadores do direito à proteção do patrimônio genético humano e as informações genéticas contidas no genoma humano como bens de interesses difusos. 2000. Disponível em: <http://www.ghente.org/publicacoes/ limite/principios.htm\# ftn1>. Acesso em: 2 ago. 2016.

2 (LEVINE, 1977, p. 3-6 apud DIAFÉRIA, 2000). DIAFÉRIA, Adriana. Princípios estruturadores do direito à proteção do patrimônio genético humano e as informações genéticas contidas no genoma humano como bens de interesses difusos. 2000. Disponível em: < http://www.ghente.org/publicacoes/ limite/principios.htm\# ftn1>. Acesso em: 2 ago. 2016.

3 DIAFÉRIA, Adriana. Princípios estruturadores do direito à proteção do patrimônio genético humano e as informações genéticas contidas no genoma humano como bens de interesses difusos. 2000. Disponível em: <http://www.ghente.org/publicacoes/limite/principios.htm\#_ftn1>. Acesso em: 2 ago. 2016.

4 BARBAS, Stela Marcos de Almeida Neves. Direito do genoma humano. Coimbra: Almedina, 2007. p. 12-13. (grifo do autor).

5 PEREIRA DO VALE, 1997, p. 143 apud DIAFÉRIA, 2000. DIAFÉRIA, Adriana. Princípios estruturadores do direito à proteção do patrimônio genético humano e as informações genéticas contidas no genoma humano como bens de interesses difusos. 2000. Disponível em: <http://www.ghente.org/ publicacoes/limite/principios.htm\#_ftn1>. Acesso em: 2 ago. 2016.

6 Op. cit. 4, p. 13.

7 BARACHO, José Alfredo de Oliveira. A identidade genética do ser humano: bioconstituição: bioética e direito. Revista de Direito Constitucional e Internacional, São Paulo, ano 8, n. 32, p. 88-92, jul./set. 2000. Disponível em: <http://www.jurisite.com.br/textosjuridicos/texto74.html>. Acesso em: 3 ago. 2016.

8 UNESCO. Declaração universal do genoma humano e dos direitos humanos. 1997. Elaborado pelo Comitê Internacional de Bioética, da UNESCO (Organização das Nações Unidas para a Educação, a Ciência e a Cultura), e apresentado na $29^{\text {a }}$ Sessão da Conferência Geral da UNESCO, que aconteceu entre os dias 21 de outubro a 12 de novembro de 1997. Disponível em: <http://wwwl.folha.uol.com. br/fsp/1997/11/15/mundo/13.html>. Acesso em: 11 ago. 2016.

9 Op. cit. 8.

10 Para alguns autores o termo gerações poderia desencadear a falsa ideia de que conforme fossem evoluindo, ocorreria uma substituição de uma geração por outra, razão pela qual utilizam a expressão "dimensão", e não geração.

11 CANOTILHO, José Joaquim Gomes. Direito Constitucional: e a teoria da constituição. 7. ed. Coimbra: Almedina, 2003. p. 383.

12 MIRANDA, Jorge. Manual de Direito Constitucional: tomo iv, direitos fundamentais. Coimbra: Editora Coimbra, 2012. p. 7. (grifo do autor).

13 MARRONI, Fernanda. Quais são as dimensões de direitos fundamentais? 2011. Disponível em: <http://ww3.lfg.com.br/public_html/article.php?story=2011062115424915>. Acesso em: 4 ago. 2016.

14 MORAES, Alexandre de. Direito constitucional. 29. ed. São Paulo: Atlas, 2013. p. 29.

15 PÉREZ LUÑO, Antonio-Enrique. La tercera generación de Derechos Humanos. Navarra: Arazandi, 2006. p. 28.

16 Contaminación de las libertades.

17 Op. cit. 13.

18 BONAVIDES, Paulo. Curso de direito constitucional. 25. ed. São Paulo: Malheiros, 2011. p. 571.

19 Op. cit. 18. p. 572. (grifo do autor).

20 BOBBIO, Noberto. A era dos direitos. Tradução de Carlos Nelson Coutinho. Rio de Janeiro: Elsevier, 2004. p. 26.

21 Op. cit. 20, p. 26.

22 Op. cit. 20, p. 25.

23 MOTTA FILHO, Sylvia Clemente da; BARCHET, Gustavo. Curso de direito constitucional. 2. ed. Rio de Janeiro: Elsevier, 2009. p. 96.

24 BOBBIO, Noberto. A era dos direitos. 10. ed. Rio de Janeiro: Campus, 1992. p. 14.

25 MENDES, Jéssica Coura. Direitos de quarta dimensão. 2014. Disponível em: <https://jus.com.br/ artigos/27836/direitos-de-quarta-dimensao >. Acesso em: 7 ago. 2016.

26 MALUF, Adriana Caldas do Rego Freitas Dabus. Curso de bioética e biodireito. 3. ed. São Paulo: Atlas, 2015. p. 117.

27 Op. cit. 4, 296-297.

28 Op. cit. 4, p. 297. 
29 Op. cit. 3.

30 Op. cit. 4, p. 299

31 MORGATO, Melissa Cabrini. Bioética e direito: limites éticos e jurídicos na manipulação do material genético. São Paulo: Letras Jurídicas, 2011. p. 124.

32 Op. cit. 15, p. 137.

33 No original, La tensión surge, precisamente, de la exigencia de los poderes públicos de utilizar la transmisión de esos datos médicos, especialmente de los que hacen referencia a enfermedades contagiosas, o de aquellos que pueden ser utilizados para el desarollo de avances en la investigación científica y el deseo de los cuidadanos de mantener un control sobre las informaciones que les conciernen.

34 DAVARA RODRÍGUEZ, Miguel Ángel. Manual de derecho informático. 10 ed. Navarra: Arazandi, 2008. p. 55.

35 SOUZA, Paulo Vinicius Sporleder de. Biobancos, dados genéticos e proteção jurídico-penal da intimidade. Revista da AMRIGS, Porto Alegre, v. 56, n. 3, p. 268-273, jul./set. 2012. Disponível em: < http://www. amrigs.org.br/revista/56-03/biobancos.pdf >. Acesso em: 13 ago. 2016. p. 268

36 Op. cit. 35, p. 268-269.

37 (MONTESQUIEU, 1956 apud SILVA, 2016, p. 233). SILVA, José Afonso da. Curso de direito constitucional positivo. 39. ed. São Paulo: Malheiros, 2016.

38 SILVA, José Afonso da. Curso de Direito Constitucional Positivo. 39. ed. São Paulo: Malheiros, 2016.

39 Op. cit. 38.

40 BRASIL. Constituição Federal: de 05 de outubro de 1988. In: Vade Mecum compacto. 7. ed. São Paulo: Saraiva, 2012. p. 7-92.

41 (LAFER, 1998 apud MEIRA, 2012). MEIRA, Laís Moreschi de; SOARES, Matheus Fernandes de Souza; PIRES, Panmella Rodrigues. Direito à privacidade e as relações na internet, 2012. Disponível em: <http://www.jurisway.org.br/v2/dhall.asp?id_dh=7319>. Acesso em: 13 ago. 2016.

42 BASTOS, Celso Ribeiro. Curso de direito constitucional. 21. ed. São Paulo: Saraiva, 2000. p. 55-56.

43 Op. cit. 38.

44 MEIRA, Laís Moreschi de; SOARES, Matheus Fernandes de Souza; PIRES, Panmella Rodrigues. Direito à privacidade e as relações na internet. 2012. Disponível em: <http://www.jurisway.org.br/v2/dhall. asp?id_dh=7319>. Acesso em: 13 ago. 2016.

45 DOTTI, René Ariel. Proteção da vida privada e liberdade de informação. São Paulo: RT, 1980. p. 69.

46 ECHTERHOFF, Gisele. Os dados genéticos e o direito à privacidade: a declaração universal sobre o genoma humano e os direitos humanos. Revista Eletrônica do CEJUR, Paraná, v. 1, n. 1, p. 230, ago./ dez. 2006. Disponível em: < http://www.egov.ufsc.br/portal/sites/default/files/anexos/32023-37643-1-PB. pdf>. Acesso em: 13 ago. 2016.

47 Op. cit. 46, p. 230.

48 BANDEIRA, Ana Cláudia Pirajá; SCARIOT, Tatiane Botura. Discriminação genética e direitos da personalidade: problemas e soluções. Revista Jurídica Cesumar, Maringá, v. 6, n. 1, p. 47-73, 2006. Disponível em: < http://periodicos.unicesumar.edu.br/index.php/revjuridica/article/view/308>. Acesso em: 13 ago. 2016. p. 56.

49 Op. cit. 48, p. 57.

50 Op. cit. 46, p. 232.

51 Op. cit. 46, p. 235.

52 Op. cit. 3.

53 BRASIL. Lei n ${ }^{\circ} 12.965$, de 23 de abril de 2014. Estabelece princípios, garantias, direitos e deveres para o uso da Internet no Brasil. Diário Oficial da República Federativa do Brasil, Brasília, DF, 24 abr. 2014. ed. 77. Seção 1.p.1. Disponível em < http://www.planalto.gov.br/ccivil_03/2014/lei//12965.htm>. Acesso em: 10 ago. 2016.

54 Op. cit. 53.

55 Op. cit. 53. (grifo nosso).

56 BRASIL. Decreto no 8.771, de 11 de maio de 2016. Regulamenta a Lei no 12.965, de 23 de abril de 2014, para tratar das hipóteses admitidas de discriminação de pacotes de dados na internet e de degradação de tráfego, indicar procedimentos para guarda e proteção de dados por provedores de conexão e de aplicações, apontar medidas de transparência na requisição de dados cadastrais pela administração pública e estabelecer parâmetros para fiscalização e apuração de infrações. Diário Oficial da República Federativa do Brasil, Brasília, DF, 11 mai. 2016. ed. extra. p.7. Disponível em <http://www.planalto. gov.br/ccivil_03/_Ato2015-2018/2016/Decreto/D8771.htm>. Acesso em: 14 ago. 2016. 
57 op. cit. 56.

58 op. cit. 56.

59 Diferentes ações para cada tipo de usuário.

60 Registro de acessos contendo alguns dados relevantes, como por exemplo, usuário, ação realizada, duração, dentre outros.

61 Técnicas para cifrar a escrita.

\title{
THE PROTECTION OF HUMAN GENETIC HERITAGE AND GENETIC INFORMATION CONTAINED IN BIOBANKS
}

\begin{abstract}
A globalized world and technological and human development generate positive and negative impacts on the social environment. The context under analysis regards the concern that jurists have in drawing guidelines to safeguard, protect and limit paradigms aiming to protect the human genetic heritage and to preserve fundamental rights. The research is justified by the need for protection of the human genetic heritage and the respective genetic information contained in biobanks. Through literature and legislative review, the article questions whether the genetic information of people stored in biobanks are safe and if the content of biological databases is encompassed by the concept of database prescribed by the Brazilian legislation on the civilian use of the internet and its regulatory decree. The article concludes that the data contained in the biological databases fits the aforementioned concept of database; however, given that it is related to human genetic heritage, the established safety standard requires better regulations, to provide greater safety and rigor in the legislation aiming at the protection of intimacy and privacy.
\end{abstract}

Keywords: Human genetic heritage. Genetic information. Protection. Biobanks.

Submetido: 17 ago. 2016

Aprovado: 30 set. 2016 